\title{
The effect of task modality and discourse mode on EFL learners' narrative task performance
}

\author{
Majid Asgari and Sakineh Jafari \\ Islamic Azad University of Hidaj | Islamic Azad University of Zanjan
}

This study examined the effect of task mode (written vs. spoken) and discourse mode (pair vs. individual) on advanced Iranian EFL learners' task performance. Participants, four groups of advanced learners, performed a narrative task in four conditions: the first group of participants performed the task individually in a spoken mode, the second group performed the task individually in a written mode, the third group performed the task in pairs in a spoken mode, and the participants in the fourth group performed the task in pairs in a written mode. The results indicated that the participants' performances, in terms of complexity, accuracy, and fluency improved greatly among learners who worked in pairs rather than individually, and those who performed written tasks rather than oral ones.

Keywords: accuracy, complexity, discourse mode, fluency, task mode, task performance

\section{Introduction}

During the 1970s and 1980s developing L2 learners' communicative competence has been identified as the primary goal of language instruction (Brumfit \& Johnson, 1979; Geddes \& Sturtridge, 1979; Morrow, 1979; Widdowson, 1978). To establish this goal, the use of tasks, as opposed to the previously dominant presentation, practice, production ( $3 \mathrm{Ps}$ ) model, has been gradually evolved in language pedagogy. According to Ellis (2017), this advocacy of task based language teaching (TBLT) led to the rise of a movement against traditional methods of language teaching. Skehan $(1998,2009)$, in keeping with the processing perspective of language acquisition, puts forward two justifications for the use of pedagogical tasks. The first, which pertains to information-processing load and the difficulty of the task, assumes that attentional resources are limited and devoting attention to one 
aspect of performance may divert attention away from other aspects. The second rationale, selective channeling, is concerned with the relationship between main aspects of language production (complexity, accuracy, fluency) and task characteristics, which presumes that the task draws learners' attention to various aspects of performance in different ways.

There has been much research in the field of TBLT on how language performance can be affected by task characteristics and task conditions. For instance, studies on the effect of task characteristics have shown that structured tasks lead to greater fluency as well as greater accuracy in learners' performance (e.g., Foster \& Skehan, 1996; Skehan \& Foster, 1997, 1999). Also, greater fluency and accuracy have been achieved in tasks with familiar information (e.g., Foster \& Skehan, 1996; Skehan \& Foster, 1997). In addition, findings of empirical studies have revealed that complex tasks result in more accurate, complex and structurally varied performance compared to simple tasks (e.g., Choong, 2011; Fukuta \& Yamashita, 2015; Kuiken \& Vedder, 2008; Shiau \& Adams, 2011). In the same vein, Robinson (2001, 2005, 2007) strongly asserts that cognitively complex tasks assist learners in developing a balanced interlanguage regarding accuracy, fluency, and complexity.

A number of other researchers have focused on the effect of task conditions on L2 performance. As Skehan (1998) argued, in order to maintain a fair balance among the three goals of complexity, accuracy, and fluency in L2 learners' production, tasks should be implemented in a number of ways. According to Skehan (1998, 2003), pedagogic interventions at the pre-task, within-task, and post-task phases may contribute to the systematic manipulation of attentional resources. A number of studies which have concentrated on the impact of pre-task planning (e.g., Abram \& Byrd, 2016; Ellis, 1987; Foster \& Skehan, 1996, 1999; Kim, 2013; Park, 2010; Philp, Oliver, \& Mackey, 2006; Skehan \& Foster, 1997; Yuan \& Ellis, 2003) supported the positive effect of planning on fluency and complexity. Studies conducted on the impact of within-task planning or on-line planning (e.g., Ahmadian, 2012; Ellis, 1987; Ellis \& Yuan, 2004; Sangarun, 2005) indicated that planning one's attentional resources at the time of doing the task enables learner to focus more on accuracy. Moreover, studies on post-task effect (e.g., Fukunta, 2015; Saeedi \& Rahimi Kazerooni, 2014; Skehan \& Foster, 1997, 2002) have demonstrated the beneficial effect of activities such as transcribing one's speech or re-doing the task publicly or privately on learners' accuracy.

A whole host of these studies have focused on spoken language. Written performance has recently attracted TBLT researchers' interest (e.g., Abram \& Byrd, 2016; Byrnes \& Manchón, 2014; Kuiken \& Vedder, 2008, 2012; Ong \& Zhang, 2010). However, to date only few studies (e.g., Kormos \& Trebits, 2012; Kuiken \& Vedder, 2012; Vasylets, Gilabert, \& Manchón, 2017) have included both modes of 
performance in a single study to compare their effects on EFL learners' production. In addition, most of the researchers used individual or pair work in their studies, rather than using both in a single study. Few attempts have been made to compare the difference in learners' performance in terms of individual and pairwork (e.g., Dobao, 2012; Kuiken \& Vedder, 2002; Nassaji \& Tian, 2010; Storch, 2005; Wigglesworth \& Storch, 2009).

\section{Review of the literature}

\subsection{Collaborative vs. individual task performance}

From a sociocultural point of view, social interaction is an important prerequisite for learning (Vygotsky, 1978, 1986). According to Vygotskian sociocultural theory, learning is essentially a social enterprise and the full development of human cognition cannot be achieved by individual learning. Central to this theory is the concept of ZPD (zone of proximal development), which is defined by Vygotsky (1978) as "the distance between the actual developmental level as determined by independent problem solving and the level of potential development as determined through problem solving under adult guidance or in collaboration with more capable peers" (p. 86). Collaboration is fundamental to the notion of ZPD, indicating that learners' social interaction within their ZPD, helps them in filling the gaps in their knowledge and extending it to the level where they cannot learn independently anymore (Aljaafreh \& Lantolf, 1994; Donato, 1994; Nassaji \& Swain, 2000).

In light of this shift of perspective from cognitive to social orientation, engaging language learners in collaborative activities has been widely advocated by second language acquisition researchers and practitioners. Several empirical studies have undertaken to examine the role of collaboration in L2 learning (e.g. García Mayo, 2002a, 2002b; Kowal \& Swain, 1994; Kuiken \& Vedder, 2002; Leeser, 2004; Nabei, 1996; Storch, 1998, 2005, 2007; Swain \& Lapkin, 2001, 2002). One of the seminal studies which focused on the effectiveness of collaborative output construction on L2 learning was conducted by Kowal and Swain (1994). The results showed that producing language collaboratively provided learners with an opportunity to notice gaps in their knowledge of language, to attend to the relationship between form and meaning, and to receive correction on their performance from their peers.

A few studies have also made a comparison between individual and collaborative pair work. For instance, Kuiken and Vedder (2002) examined Dutch ESL students' collaborative pair work on completing a dictogloss task. The results showed 
many instances of learner interaction in which learners' attention was drawn to the target form. However, the comparison of the pre-test and post-test did not reveal a significant effect for collaborative pair work.

Storch (2005) also investigated the difference between individual and pair written products of L2 learners. Learners' written outputs were examined in terms of accuracy, fluency and complexity. Also, the nature of learners' interaction during collaboration was explored. The results indicated that the collaborative pair work provided learners with more opportunities to exchange ideas and peer feedback. In addition, collaborative written outputs resulted in shorter but grammatically more accurate and more complex texts compared to individual written outputs. However, these differences were not significant. This lack of significance according to Storch (2005) might be attributed to the short length of the editing text and the small sample size of participants in her study.

In another study, in an assessment context, Wigglesworth and Storch (2009) compared the performance of learners in pair and individual writing. The findings indicated that working in pairs allowed learners to produce more accurate texts compared to the texts produced individually by learners. In addition, qualitative analyses of the results suggested that, in terms of the process of writing, collaboration provided the learners with an opportunity to generate and share more ideas on different aspects of writing.

The above studies may point to the conclusion that collaborative pair work may foster L2 learners' interaction and attention to language forms, but it may not necessarily lead to superior performance compared to individual work. However, as Storch $(2005,2009)$ and Kuiken and Vedder (2002) emphasized, studies in this area are still very limited, and therefore further research is required.

\subsection{Written vs. spoken task performance}

One coherent model of speech production is proposed by Levelt (1989) and comprises of three processing stages: conceptualization, formulation, and articulation. In the conceptualization stage, the speaker decides about the specific communicative goals according to the situational factors. In the formulation stage, speech planning happens, in which language forms (such as lexical, grammatical and phonological features) of the pre-verbal messages are determined. In the last stage, speech plans are converted into actual speech and speech production takes place. Levelt (1989) argues that these stages function in a parallel fashion and are regulated by a self-monitoring process. The formulation and articulation components of speech production processes operate under controlled processing while the conceptualization stage operates automatically. 
A very similar model, which is proposed by Kellogg (1996) for written production, distinguishes three stages for writing; formulation, execution, and monitoring. In the formulation stage, the writer formulates a plan about the goals of writing and also translates the required lexical units and selects the essential syntactical features to encode ideas. In the execution stage, which entails programming, the output from the translation is transformed into sentence production. In the last stage, which occurs before or after the execution of a sentence, the writer edits the written production. As Kellogg (1996) maintains the central executive component of the working memory is evident in all the components of the model, with the exception of the execution stage in which the need to controlled processing is reduced. Therefore, the amount of planning available for learners differs in these three stages of language production. Unlike the execution stage, which requires more automatic processing, some degree of planning is involved in the monitoring and formulation stages (Bygate \& Samuda, 2005).

Although these two models overlap to some extent, there exists a number of key differences between speaking and writing. According to Grabe and Kaplan (1996) writing is not constrained by time and it is a cyclical process, in which writers can plan, encode and revise their production. Ellis (1987) also states that writing, in comparison to speaking, is generally more planable. As Skehan (1998) argues, in spoken tasks due to the pressure of real-time performance, less time will be devoted to on-line planning and attention to form. Therefore, learners mostly focus on fluency, and as a result less attention will be directed to accuracy and complexity. In contrast, written tasks will enable learners to manipulate their resources to some extent, and to have some degree of choice in how to allocate their attention (Skehan, 1998; Williams, 2012). In the same line, Brown (2001) asserts that unlike speaking, which necessitates a great amount of redundancy, writing entails a greater variety of lexical items, longer clauses and more subordinations. In addition, a longitudinal study by Weisburg (2000) demonstrated that L2 learners apply more new syntactic forms and more low-frequency words in their written production compared to their spoken output.

In the field of ELT, only few studies have concentrated on how the mode of performance influences L2 learners' production. In a study conducted by Kormos and Trebits (2012), the effects of task complexity and foreign language aptitude on oral and written performances of Hungarian EFL learners were examined. The results indicated that participants used more accurate language and more varied vocabulary in writing than in speech. With regard to syntactic complexity, however, no significant differences were found in participants' task performances. In addition, an interaction between task type and performance mode was found, suggesting that tasks with varied cognitive demands might result in different patterns of production in writing and speech. 
In a similar study, Kuiken and Vedder (2012) examined the impact of task complexity on the performance of Dutch learners of Italian as a second language in written and spoken mode. The findings of their study showed that task complexity had a great impact on learners' accuracy both in the oral and written mode of performance. Moreover, no interaction was found between task type and proficiency level, either in the written or in the oral mode.

In a recent study, Vasylets, et al. (2017) studied the impacts of mode (oral vs. written) and task complexity on Spanish EFL learners' performance. The participants were assigned into two groups to perform the simple and complex tasks orally and in writing. The comparison of the participants' oral and written performance showed that the oral mode resulted in the production of more idea units, however; the written mode led to higher scores in terms of length of analysis-ofspeech (AS) units, lexical richness, and longer idea units. In addition, the results revealed that participants, both in oral and written modes, produced longer AS units, more subtle words, and more ideas in the complex task, compared to the simple condition.

Zalbidea (2017) also found that task modality moderated all of the dimensions of L2 output. In oral tasks, participants produced syntactically more complex language. However, in written tasks, participants constructed lexically more diverse as well as more accurate language.

Moreover, Payant and Kim (2017) suggested that task designers should pay close attention to task modality: oral tasks could result in more activation of ideas and written tasks lead learners to engage more in collaborative dialogue. They concluded that "The combination of two modalities can foster communicative competence and balance learners' attention to both lexis and form thereby pushing them to address questions or gaps in their linguistic knowledge" (p.12).

As the above review indicates, few studies have focused on the effects of pair vs. individual as well as oral vs. written on EFL learners' task performance. Thus, the present study made an attempt to examine and compare the effectiveness of mode of performance (oral vs. written) as well as discourse mode (pair vs. individual) on Iranian EFL learners' narrative task performance in terms of complexity, accuracy, and fluency. No study thus far has investigated the effect of these variables on EFL learners' task performance in a single study. In order to fulfill the purposes of the present study the following research questions were formulated:

1. Does task modality (written /oral) affect advanced EFL learners' performance in terms of accuracy, fluency and complexity?

2. Does discourse mode of performance (individual/ pair) affect advanced EFL learners' performance in terms of accuracy, fluency and complexity?

3. Which task performance condition leads to better performance in terms of accuracy, fluency and complexity? 


\section{Method}

\subsection{Participants}

A total of 58 advanced EFL learners (four intact classrooms) who were studying English in a private language school in Zanjan, Iran were selected through convenience sampling. This language school presented various general English courses for different levels of proficiency, ranging from beginning to advanced levels. The main course book taught in the institute was Top Notch series (second edition) written by Joan Saslow \& Allen Ascher (2012). The participants of this study were studying Summit $2 \mathrm{~A}$ and $2 \mathrm{~B}$ and they were considered as advanced level according to the language institute standards and the placement tests that they had taken (i.e. Oxford Placement Test). All of the participants were female, between 17-21 years old and none had ever been to an English-speaking country. They were assigned into four groups.

\subsection{Materials}

A narrative task (taken from Ur, 1991,p.56) which consisted of a series of pictures was utilized to achieve the purpose of this study. The task required the learners to construct an oral or written story, individually or in pairs, on basis of the pictures (see Appendix). The pictures were the same for learners in all 4 conditions and were already ordered in the correct sequence. As Skehan \& Foster (1999) assert narrative stories are tasks "supported by visual material, but which require some degree of organization of material to tell a story effectively" (p.98) and are used by many researchers in other similar task-based studies. In terms of cognitive load, this narrative task required interpretation on the part of the participants since in this picture series different numbers of participants and elements were present (Candlin, 1987).

\subsection{Measures}

Three measures are generally used to analyze learners' performance in TBLT: complexity, accuracy and fluency:

Complexity has been measured in different ways by $\mathrm{L} 2$ researchers. For instance, Yuan and Ellis (2003) defined complexity as the ratio of clauses to T-units. A Tunit (or Terminable Unit) is defined as "the shortest unit which a sentence can be reduced to, and consisting of one independent clause together with whatever dependent clauses are attached to it, generally used to measure written language" (Richards \& Schmidt, 2002,p.13). However, as subordination may decrease with 
L2 proficiency, Bulté and Housen (2012) suggested using analysis of the mean length of units instead. Foster, Tonkyn, and Wigglesworth (2000) have proposed the use of the AS-unit (Assessment of Speech ) as a unit of complexity measurement. An AS-unit is defined as “a single speaker's utterance consisting of an independent clause or sub-clausal unit, together with any subordinate clause(s) associated with it" (Foster et al., 2000, p.365). They argue that this is more appropriate for spoken language than T-unit which is more appropriate for written language. Norris and Ortega (2009) also came to the conclusion that most of the studies have used mean length of T-unit for measuring overall complexity, mean number of clauses per T-unit for measuring complexity by subordination, and mean length of clause for measuring for phrasal elaboration.

The second variable, accuracy, has also been measured in various ways in L2 research including the percentage of error-free clauses of the whole number of clauses, the ratio of error-free T-units to overall T-units or to the total number of clauses or to the total number of words, weighted T-unit measures, analyses of different error-types, and error-severity (see Polio \& Shea, 2014, and Foster \& Wigglesworth, 2016 for more information). Mehnert (1998), also argues that it is more accurate to measure grammatical accuracy as the number of errors per 100 words since clauses can be of different lengths.

Fluency, the third component of complexity, accuracy, and fluency (CAF), has been typically measured in different studies as a number of syllables produced per minute of speech or the number of words produced within a time limit (Hudson, Lane, \& Mercer, 2005; Ong \& Zhang, 2010). To allow cross-study comparisons, and concerning the assessment of the learners' performance, syntactic complexity was measured by the number of clauses per T-units; accuracy was measured in terms of error-free T-units; and fluency was measured in terms of the number of words produced within a time limit.

\subsection{Procedure}

At the beginning of the study, to ensure the homogeneity of the participants, the Oxford Placement Test (OPT) was given to the learners. The results ascertained that they were at an equal level of general proficiency. Then, the assigned narrative task was given to the learners to construct an oral or written story individually or in pairs. Participants in the first group $(n=13)$ were asked to construct an oral story individually; the ones in the second group $(n=15)$ were asked to make written story individually; the learners in the third group $(n=14)$ were asked to construct an oral story in pairs, and finally those in the fourth group $(n=16)$ were asked to construct a written story in pairs (i.e. in the pair performance, both learners were asked to contribute equally to the performance of the task). 
A series of pictures were given to the learners in all groups. After data collection, the obtained scores (accuracy, complexity and fluency scores) from performances of four groups were submitted to statistical analysis. All data was collected during normally scheduled class time. Participants were given 10 minutes to complete the task and told to write or tell the story in pairs or individually, while the researchers did not give any special guidance with respect to formal features, organizational points, or the content. The time required for task completion was piloted by 12 participants ( 3 participants per condition) who had characteristics similar to the participants in the main study. Following Ellis and Yuan (2004) who stated that the time required for a task is the fastest time in which learners can perform the task, the participants were asked to accomplish the tasks as fast as possible. In all cases, the time at which the first participants finished their task (i.e. after1o minutes) was regarded as the task completion time required.

After data collection, the researcher transcribed the recorded data (oral stories) and analyzed them in terms of three production measures of complexity, accuracy, and fluency (CAF). The written stories were also analyzed in terms of $\mathrm{CAF}$. The results have been reported in the following sections.

\section{Results}

In order to answer the research questions, a series of two-way ANOVAs were carried out through SPSS software version 21. Table 1 summarizes the results of descriptive statistics.

Table 1. Descriptive Statistics: Mean scores of complexity, accuracy, and fluency

\begin{tabular}{llcccc}
\hline Modality & $\begin{array}{l}\text { Discourse } \\
\text { mod }\end{array}$ & $\begin{array}{c}\text { Number of } \\
\text { participants }\end{array}$ & $\begin{array}{c}\text { Mean } \\
\text { complexity }\end{array}$ & $\begin{array}{c}\text { Mean } \\
\text { accuracy }\end{array}$ & $\begin{array}{c}\text { Mean } \\
\text { fluency }\end{array}$ \\
\hline Oral & Individual & $(n=13)$ & 13.35 & 8.99 & 12.01 \\
& Pair & $(n=14)$ & 13.98 & 12.14 & 15.41 \\
\multirow{2}{*}{ Written } & Individual & $(n=15)$ & 13.93 & 10.93 & 14.40 \\
& Pair & $(n=16)$ & 15.75 & 15.81 & 14.40 \\
\hline
\end{tabular}

The descriptive statistics (Table 1) show that for the two categories (modality and discourse mode) regarding complexity, accuracy, and fluency, the mean scores for pairs were generally higher than the mean scores of the participants who performed their tasks individually. Comparing the oral and written condition of the study, it can generally be claimed that the participants who performed the task orally received lower mean scores than those learners who performed written tasks. Thus, participants' performances, with regard to complexity, accuracy, and 
fluency were improved greatly among learners who worked in pairs rather than individually and among those who performed written tasks rather than oral ones.

Table 2. Results of 2-way ANOVA

\begin{tabular}{lrrrrrr}
\hline & \multicolumn{2}{c}{ Complexity } & \multicolumn{2}{c}{ Accuracy } & \multicolumn{2}{c}{ Fluency } \\
\cline { 2 - 7 } & \multicolumn{1}{c}{ F } & Sig. & \multicolumn{1}{c}{ F } & Sig. & \multicolumn{1}{c}{ F } & \multicolumn{1}{c}{ Sig. } \\
\hline Modality & 3.409 & .060 & 17.890 & .020 & 4.426 & .038 \\
Discourse Mode & 14.987 & $<.001$ & 52.689 & $<.001$ & 15.578 & $<.001$ \\
Modality ${ }^{*}$ Discourse Mode & 1.463 & .300 & 1.437 & .205 & 3.452 & .069 \\
\hline
\end{tabular}

Three two-way ANOVAs were run to investigate the effects of the independent variables (modality and discourse mode) on complexity, accuracy, and fluency, respectively. Table 2 displays the results of between-subject effects for the two categories of modality and discourse mode, and their related interactions with regard to complexity, accuracy, and fluency measures.

As the table shows, for complexity, there was a significant main effect for the discourse mode. Regarding accuracy and fluency, the results indicate that there was a significant main effect for modality and discourse mode. No significant effect was observed between modality and discourse mode in terms of complexity, accuracy or fluency.

\section{Discussion}

This study examined the effect of performance mode (written vs. spoken) and discourse mode (pair vs. individual) on advanced Iranian EFL learners' narrative task performance. Four groups of advanced learners performed a narrative task in four conditions. In the first condition, learners performed the task individually in the spoken mode. In the second condition, learners performed the task individually in the written mode. Learners in the third condition, performed the task in pairs in the spoken mode. And the learners in the fourth condition performed the task in pairs in the written mode.

Overall, the results indicated that the mean scores for pairs, in terms of complexity, accuracy, and fluency, were generally higher than the mean scores of the participants who performed the task individually. Also, comparing the oral and written mode of the study, the participants who performed written tasks received higher mean scores than those who performed the task orally. In other word, the participants did better in written tasks on average. Regarding the three measures, for complexity, there was a significant main effect for the discourse mode. In terms 
of accuracy and fluency, significant main effects for modality and discourse mode were found. However, no significant main effect was found for the interactions between modality and discourse mode in terms of complexity, accuracy and fluency. Unlike other groups, in terms of accuracy, the group who performed the task individually in an oral mode did not differ significantly with the group who performed the task individually in written mode. Moreover, with regard to complexity, the group who performed the task individually in an oral mode did not differ significantly with the group who performed the task in pairs orally.

It is worth mentioning here that pair work enjoys a strong theoretical background in communicative, collaborative, interactionist, and social constructivist views of language teaching and it is highly connected to the very core of the Vygotskyan (1978) Zone of Proximal Development (ZPD). Based on the ZPD theory, less proficient learners can receive assistance from the more proficient learners in dealing with the cognitively complex tasks. In other words, ZPD advocates that it is in the interaction where a lower level learner moves from his/her actual developmental level to the potential developmental level with the help of an expert (a teacher, a parent, a peer, and the like). The distance between these two levels, that is, the actual developmental level and the level of potential development, is referred to as the ZPD (Vygotsky, 1978).

Many researchers have confirmed the leading role that pair work, as a collaborative learner-centered approach to teaching, might have in EFL/ESL settings (e.g., Achmad \& Yusuf, 2014; Nassaji \& Tian, 2010). Achmad and Yusuf (2014) for instance support the idea that pair work can increase L2 students' motivation in an EFL classroom. They suggest that through dyadic interaction, learners will interact with their partners more actively compared to individual work or group work where some students may dominate the interaction episode while others may be apathetically passive. As Ellis (2003) claims collaborative task performance can assist language learners to perform beyond their own individual capacities and would offer them opportunities to scaffold each other's performance. However, it should be mentioned that allowing the language learners to work on tasks individually might enable learners to engage in private manipulation and experimentation with the target language. Therefore, in some cases, individual work may help EFL/ESL learners to foster independence and autonomy in their process of learning (Skehan, 1998; Lantolf, 2000). As Storch (2005) concluded, although the collaborative pair work led to many opportunities for exchanging ideas and peer feedback, the difference between the individual and pair work was not statistically significant in her study. According to Harmer (2007), one of the disadvantages of group or pair work is that learners may often speak in their native language. Also, in the group and pair work shy and weak students may be eliminated from the practice. 
Moreover, a better written performance of participants in this study may be linked to the fact that learners may focus closely on the content and form of their performance. This confirms the findings of Kuiken and Vedder (2012) and Vasylets, et al. (2017). Writing task offers participants enough time to focus on the formal features of their production and to devote more attentional capacity to the formation of their sentences which in turn lead to more accurate, fluent and complex utterances. As Skehan (1998) asserts, oral tasks will permit less time to be allocated to on-line planning and attention to form because pressure of realtime performance will push the students to satisfy the need for adequate fluency, so that less attention is available elsewhere. In contrast, written tasks will enable learners to marshal their resources to some extent, and as a result, have some degree of choice in how they allocate their attention. In addition, Skehan (1998) argues that modality plays a leading role in the amount of cognitive load and allocation of attention, as the real-time processing demands of spoken language leave little opportunity for attention to form, whereas writing may give more space to learners to focus their attention to form. It may be said that allocating more processing time in generating written performance, offered participants of this study opportunity to attend more to their performance, and as a result, generate more accurate, fluent, and complex language in a less stressful setting.

\section{Conclusion}

Two broad conclusions can be drawn from the findings of this study. First, it should be mentioned that pair work as an essential element in EFL/ESL classes has a clear effect on students' performance during speaking and writing tasks since it is assumed that when learners work together within their ZPD, a less capable learner can be helped by a more knowledgeable one to develop his or her language knowledge (Aljaafreh \& Lantolf, 1994). EFL learners are interested in, and motivated by working with their peers; hence, pair work helps them to enhance their communication skills and provides more opportunities for L2 learners to learn the language in a meaningful context (Nassaji \& Tian, 2010). As mentioned earlier, pair work is the cornerstone of collaboration in EFL speaking classes. Moreover, dyadic interaction provides learners with the opportunity to maximize their participation in performing the tasks. According to Achmad and Yusuf's (2014) study, pair work is more efficient than group or whole class discussions as in a dyadic interaction, every student, especially introverted ones, get the opportunity to speak, students correct each other's mistakes and help each other with vocabulary needed. Through pair work the interaction develops in a social context, and students learn politeness, turn-taking, and respect towards 
each other while doing the tasks required. Students in pairs have the opportunity to work autonomously with minimal teacher involvement. And finally pair work has the potential to increase students' fluency through engagement in conversational interactions in a natural, meaningful and communicative setting (see Achmad \& Yusuf, 2014).

The second conclusion here is that L2 production is influenced by the type of production: either spoken or written. According to Kuiken and Vedder (2012), the studies on the difference between the spoken and written productions relate to the cognitive process of the task. Towell, Hawkins, and Bazergui (1996) agreed that speaking is a more cognitively demanding task than writing and suggested that compared to writing, speaking involves much more processing of implicit knowledge about L2 grammar. Furthermore, L2 learners can more easily retrieve explicit knowledge of L2 grammar for writing because they are under less time pressure. In the same lines, Kim, Nam, and Lee (2016) suggest that speaking is different from writing in many aspects, including verbalization time, preplanning, memory, and the use of implicit versus explicit knowledge. They further argue that gathering one's thoughts can take less time for speaking than for writing, and preplanning is easier for writing than for speaking. Based on their study, it is assumed that in order to speak coherently language learners must remember previous messages and plans in the process of speaking, whereas in writing, individuals can easily retrieve those messages and plans by referring to what they had written down during the preplanning stage.

\section{Pedagogical implications}

The current study can inform teachers, syllabus designers, and material developers and it may be of particular relevance for communicative approaches such as TBLT in SLA instruction. In this study it was revealed that pair work has a considerable impact on the performance of the EFL learners and written tasks are generally easier than spoken tasks for EFL learners to perform.

A true communicative activity should provide real and meaningful contexts for communication. As Yu (2008) pointed out, classroom interaction must be seriously meaningful about matters of serious concern to the participants. EFL instructors need to keep in mind that pairwork or group work is considered to be the most interactive classroom interaction pattern that contributes to real and meaningful L2 communication. Keeping this in mind, language teachers should plan their teaching activities in a way that learner interaction is maximized through pairwork interaction. 
Since written tasks contribute more to the development of accuracy, fluency, and complexity, it is advisable that EFL learners and teachers take advantage of this finding and attempt to improve their writing skills in a task-based setting. They may also expand the findings here and try to find ways to help improve their oral performance. For example, by providing extra time for students to think and plan before they talk, teachers can help in maximizing learners' performance in terms of accuracy, fluency, and complexity.

\section{Limitations of the study}

As in all studies, the researchers of this study are confronted with the inevitable limitation related to the sample size. The sample size for this study was not large, and thus, further research is needed to make stronger generalizations. The second limitation is that the participants came from one language institute, so there is only one learning context here. Obviously, studying in a variety of school contexts would have helped to corroborate the conclusions presented in this research project. And the third limitation deals with the fact that just one type of task (i.e. narrative task) was utilized in this study. Different results may be obtained if other types of tasks will be performed. Thus, future studies need to take a deeper look into the different aspects of task-based language teaching in a variety of EFL/ESL contexts. Also, due to practicality issues, this study was limited to female learners only. Future researchers may take into account both male and female learners' performances to find out if accuracy, fluency, and complexity are gender-bound. In addition, advanced level learners participated in this study. Replication can be done with intermediate and beginner level EFL learners to see if the same results are achieved. Therefore, another important avenue for future research would be extending the research questions posed here to other tasks, conditions, contexts, and learners.

\section{References}

Abram, Z.I., \& Byrd, D. R. (2016). The effects of pre-task planning on L2 writing: Mindmapping and chronological sequencing in a 1st-year German class. System, 63, 1-12. https://doi.org/10.1016/j.system.2016.08.011

Achmad, D., \& Yusuf, U.Q. (2014). Observing pair-work task in an English speaking class. International Journal of Education, $7(1), 151-164$.

Ahmadian, M.J. (2012). The effects of guided careful online planning on complexity, accuracy and fluency in intermediate EFL learners' oral production: The case of English articles. Language Teaching Research, 16(1), 129-149. https://doi.org/10.1177/1362168811425433 
Aljaafreh, A., \& Lantolf, J. (1994). Negative feedback as regulation and second language learning in the zone of proximal development. Modern Language Journal, 78(4), 465-483. https://doi.org/10.1111/j.1540-4781.1994.tbo2064.x

Brown, H. D. (2001). Teaching by principles: An interactive approach to language pedagogy. White Plains, NY: Pearson Education.

Brumfit, C. J., \& Johnson, K. (1979). The communicative approach to language teaching. Oxford: Oxford University Press.

Bygate, M., \& Samuda, V. (2005). Planning and task performance in a second language. Amsterdam: John Benjamins.

Byrnes, H., \& Manchón, R. M. (Eds.). (2014). Task-based language learning - Insights from and for L2 writing. Amsterdam: John Benjamins. https://doi.org/10.1075/tblt.7

Bulté, B., \& Housen, A. (2012). Defining and operationalizing L2 complexity. In A. Housen, F. Kuiken, \& I. Vedder (Eds.), Dimensions of L2 performance and proficiency: Complexity, accuracy and fluency in SLA (pp. 21-46). Amsterdam: John Benjamins. https://doi.org/10.1075/lltt.32.02bul

Candlin, C. (1987). Towards task-based language learning. In C. Candlin, \& D. F. Murphy (Ed.), Language learning tasks (pp. 5-22). Englewood Cliffs: Prentice-Hall.

Choong, K.P. (2011). Task complexity and linguistic complexity: An exploratory study. Teachers College, Columbia University Working Papers in TESOL \& Applied Linguistics, $11(1), 1-28$.

Dobao, A.F. (2012). Collaborative writing tasks in the L2 classroom: Comparing group, pair, and individual work. Journal of Second Language Writing, 21(1), 40-58. https://doi.org/10.1016/j.jslw.2011.12.002

Donato, R. (1994). Collective scaffolding in second language learning. In J. P. Lantolf, \& A. Gabriela (Eds.), Vygotskian approaches to second language research (pp. 33-59). Norwood, NJ: Ablex.

Ellis, R. (1987). Interlanguage variability in narrative discourse: Style shifting in the use of the past tense. Studies in Second Language Acquisition, 9(1), 12-20. https://doi.org/10.1017/S0272263100006483

Ellis, R. (2003). Task-based language learning and teaching. Oxford: Oxford University Press.

Ellis, R. (2017). Moving task-based language teaching forward. Language Teaching, 50(4), 507-526. https://doi.org/10.1017/So261444817000179

Ellis, R., \& Yuan, F. (2004). The effects of planning on fluency, complexity, and accuracy in second language narrative writing. Studies in Second Language Acquisition, 26(1), 59-84. https://doi.org/10.1017/S0272263104261034

Foster, P., \& Skehan, P. (1996). The influence of planning on performance in task-based learning. Studies in Second Language Acquisition, 18(3), 299-324. https://doi.org/10.1017/S0272263100015047

Foster, P., \& Skehan, P. (1999). The effect of source of planning and focus of planning on taskbased performance. Language Teaching Research, 3 (3), 185-214. https://doi.org/10.1177/136216889900300303

Foster, P., Tonkyn, A., \& Wigglesworth, G. (2000). Measuring spoken language: A unit for all reasons. Applied Linguistics, 21(3), 354-375. https://doi.org/10.1093/applin/21.3.354

Foster, P., \& Wigglesworth, G. (2016). Capturing accuracy in second language performance: The case for a weighted clause ratio. Annual Review of Applied Linguistics, 36, 98-116. https://doi.org/10.1017/S0267190515000082 
Fukunta, (2015). Effects of task repetition on learners' attention orientation in L2 oral production. Language Teaching Research, 20(3), 321-340.

https://doi.org/10.1177/1362168815570142

Fukuta, J., \& Yamashita, J. (2015). Effects of cognitive demands on attention orientation in L2 oral production. System, 53, 1-12. https://doi.org/10.1016/j.system.2015.06.010

García Mayo, M.P. (2002a). The effectiveness of two form-focused tasks in advanced EFL pedagogy. International Journal of Applied Linguistics, 12(2), 156-175. https://doi.org/10.1111/1473-4192.to1-1-00029

García Mayo, M.P. (2002b). Interaction in advanced EFL pedagogy: A comparison of formfocused activities. International Journal of Educational Research, 37(3), 323-341. https://doi.org/10.1016/So883-0355(03)00008-9

Geddes, M., \& Sturtridge, G. (1979). Listening links, London: Heinemann.

Grabe, W., \& Kaplan, R.B. (1996). Theory and practice of writing: An applied linguistic perspective. New York: Longman.

Harmer, J. (2007). The practice of English language teaching (4th ed.). Essex: Pearson Education Limited.

Hudson, R. F., Lane, H. B., \& Mercer, P.C. (2005). Reading fluency assessment and instruction: What, why, and how? The Reading Teacher, 58(8), 702-714. https://doi.org/10.1598/RT.58.8.1

Kellogg, R.T. (1996). A model of working memory in writing. In C. M. Levy, \& S. Ransdell (Eds.), The science of writing: Theories, methods, individual differences and applications (pp. 57-71). Mahwah, NJ: Erlbaum.

Kim, Y. (2013). Effects of pre task modelling on attention to form and question development. TESOL Quarterly, 47(1), 8-35. https://doi.org/10.1002/tesq.52

Kim, Y., Nam, J., \& Lee, Y. (2016). Correlation of Proficiency with Complexity, Accuracy, and Fluency in Spoken and Written Production: Evidence from L2 Korean. Journal of the National Council of Less Commonly Taught Languages, 19, 147-181.

Kormos, J., \& Trebits, A. (2012). The role of task complexity, modality, and aptitude in narrative task performance. Language Learning, 62(2), 439-472. https://doi.org/10.1111/j.1467-9922.2012.00695.x

Kowal, M., \& Swain, M. (1994). Using collaborative language production tasks to promote students' language awareness. Language Awareness, 3(2), 73-93. https://doi.org/10.1080/09658416.1994.9959845

Kuiken, F., \& Vedder, I. (2002). The effect of interaction in acquiring the grammar of a second language. International Journal of Educational Research, 37(3-4), 343-358. https://doi.org/10.1016/S0883-0355(03)00009-0

Kuiken, F., \& Vedder, I. (2008). Cognitive task complexity and written output in Italian and French as a foreign language. Journal of Second Language Writing, 17(1), 48-60. https://doi.org/10.1016/j.jslw.2007.08.003

Kuiken, F., \& Vedder, I. (2012). Speaking and writing tasks and their effects on second language performance. In S. Gass, \& A. Mackey (Eds.), The Routledge handbook of second language acquisition (pp. 364-379). New York: Routledge.

Lantolf, J.P. (2000). Sociocultural theory and second language learning. Oxford: Oxford University Press.

Leeser, M. (2004). Learner proficiency and focus on form during collaborative dialogue. Language Teaching Research, 8(1), 55-81. https://doi.org/10.1191/1362168804/r1340a Levelt, W.J.M. (1989). Speaking: From intention to articulation. Cambridge, MA: MIT Press. 
Mehnert, U. (1998). The effects of different length of time for planning on second language performance. Studies in Second Language Acquisition, 20(1), 83-108. https://doi.org/10.1017/S0272263198001041

Morrow, K. (1979). Communicative language testing: Revolution or evolution? In C. J. Brumfit, \& K. Johnson (Eds.), The communicative approach to language teaching. Oxford: Oxford University Press. Also in J. C. Alderson, \& A. Hughes (Eds.) Issues in Language Testing (pp. 9-25).

Nabei, T. (1996). Dictogloss: Is it an effective language learning task? Working Papers in Educational Linguistics, 12(1), 59-74.

Nassaji, H., \& Swain, M. (2000). Vygotskian perspective on corrective feedback in L2: The effect of random vs. negotiated help on the learning of English articles. Language Awareness, 9(1), 34-51. https://doi.org/10.1080/09658410008667135

Nassaji, H., \& Tian, J. (2010). Collaborative and individual output tasks and their effects on learning English phrasal verbs. Language Teaching Research, 14(4), 397-419. https://doi.org/10.1177/1362168810375364

Norris, J.M., \& Ortega, L. (2009). Towards an organic approach to investigating CAF in instructed SLA: The case of complexity. Applied Linguistics, 30(4), 555-578. https://doi.org/10.1093/applin/ampo44

Ong, J., \& Zhang, L. J. (2010). Effects of task complexity on the fluency and lexical complexity in EFL students' argumentative writing. Journal of Second Language Writing, 26(1), 27-56.

Park, S. (2010). The influence of pre-task instructions and pre-task planning on focus on form during Korean EFL task-based interaction. Language Teaching Research, 14(1), 9-26. https://doi.org/10.1177/1362168809346491

Payant, C., \& Kim, Y. (2017). Impact of task modality on collaborative dialogue among plurilingual learners: A classroom-based study. International Journal of Bilingual Education and Bilingualism, 7(1), 1-14. https://doi.org/10.1080/13670050.2017.1292999

Philp, J., Oliver, R., \& Mackey, A. (2006). The impact of planning time on children's task-based interactions. System, 34(4), 547-565. https://doi.org/10.1016/j.system.2006.08.004

Polio, C., \& Shea, M.C. (2014). An investigation into current measures of linguistic accuracy in second language writing research. Journal of Second Language Writing, 26, 10-27. https://doi.org/10.1016/j.jslw.2014.09.003

Richards, J.C. \& Schmidt, R. (2002). Longman dictionary of applied linguistics and language teaching. Harlow, UK: Longman.

Robinson, P. (2001). Task complexity, task difficulty, and task production: Exploring interactions in a componential framework. Applied Linguistics, 22(1), 27-57. https://doi.org/10.1093/applin/22.1.27

Robinson, P. (2005). Cognitive complexity and task sequencing: Studies in a componential framework for second language task design. Annual Review of Applied Linguistics, 43(1), 1-32. https://doi.org/10.1515/iral.2005.43.1.1

Robinson, P. (2007). Task complexity, theory of mind, and intentional reasoning: Effects on L2 speech production, interaction, uptake and perceptions of task difficulty. International Review of Applied Linguistics, 45(3), 193-213. https://doi.org/10.1515/iral.2007.009

Saeedi, M., \& Rahimi Kazerooni, S. (2014). The influence of task repetition and task structure on EFL learners' oral narrative retellings. Innovation in Language Learning and Teaching, 8(2), 116-131. https://doi.org/10.1080/17501229.2013.770860 
Sangarun, J. (2005). The effects of focusing on meaning and form in strategic planning. In R. Ellis (Ed.), Planning and task performance in a second language.

Amsterdam/Philadelphia: John Benjamins. https://doi.org/10.1075/llt.11.08san

Saslow, J., \& Ascher, A. (2012). Top Notch Fundamentals teacher's edition and lesson planner (2nd ed.). New York: Pearson Education.

Shiau, Y.S., \& Adams, R. (2011). The effects of increasing reasoning demands on accuracy and complexity in L2 oral production. University of Sydney Papers in TESOL, 6, 121-146.

Skehan, P. (1998). A cognitive approach to language learning. Oxford: Oxford University Press.

Skehan, P. \& Foster, P. (2002). The effects of post-task activities on the accuracy of language during task performance. London: King's College.

Skehan, P. (2003). Task-based instruction. Language Teaching, 36(1), 1-14. https://doi.org/10.1017/So26144480200188X

Skehan, P. (2009). Modelling second language performance: Integrating complexity, accuracy, fluency and lexis. Applied Linguistics, 28, 510-532. https://doi.org/10.1093/applin/ampo47

Skehan, P., \& Foster, P. (1997). The influence of planning and post-task activities on accuracy and complexity in task based learning. Language Teaching Research, 1(3), 185-211. https://doi.org/10.1177/136216889700100302

Skehan, P. \& Foster, P. (1999). The influence of task structure and processing conditions on narrative retellings. Language Learning, 49(1), 93-120. https://doi.org/10.1111/1467-9922.00071

Storch, N. (1998). A classroom-based study: Insights from a collaborative text reconstruction task. ELT Journal, 52(4), 291-300. https://doi.org/10.1093/elt/52.4.291

Storch, N. (2005). Collaborative writing: Product, process, and students' reflections. Journal of Second Language Writing, 14(3), 153-73. https://doi.org/10.1016/j.jslw.2005.05.002

Storch, N. (2007). Investigating the merits of pair work on a text editing task in ESL classes. Language Teaching Research, 2, 143-59. https://doi.org/10.1177/1362168807074600

Storch, N. (2009). The nature of pair interaction. Learners' interaction in an ESL class: Its nature and impact on grammatical development. Saarbrücken: VDM Verlag.

Swain, M., \& Lapkin, S. (2001). Focus on form through collaborative dialogue: Exploring task effects. In M. Bygate, P. Skehan, \& M. Swain (Eds.), Researching pedagogic tasks: Second language learning, teaching and testing (pp. 99-118). Harlow: Pearson Education.

Towell, R., Hawkins, R., \& Bazergui, N. (1996). The development of fluency in advanced learners of French. Applied Linguistics, 17(1), 84-119. https://doi.org/10.1093/applin/17.1.84

Ur, P. (1991). Teaching listening comprehension. Cambridge, Cambridge University Press.

Vasylets, O., Gilabert, R., \& Manchón, R.M. (2017). The effects of mode and task complexity on second language production. Language Learning, 67(2), 394-430. https://doi.org/10.1111/lang.12228

Vygotsky, L.S. (1978). Mind in society: The development of higher psychological processes. Cambridge, MA: Harvard University Press.

Vygotsky, L.S. (1986). Thought and language. Cambridge, MA: MIT Press.

Weisburg, R. (2000). Developing relationship in the acquisition of English syntax: Writing vs speech. Learning and Instruction, 10, 37-53. https://doi.org/10.1016/S0959-4752(99)ooo17-1

Widdowson, H.G. (1978). Teaching language as communication. Oxford: Oxford University Press.

Wigglesworth, G., \& Storch, N. (2009). Pairs versus individual writing: Effects of fluency, complexity, and accuracy. Language Testing, 26(3), 445-466.

https://doi.org/10.1177/0265532209104670 
Williams, J. (2012). The potential role(s) of writing in second language development. Journal of Second Language Writing, 21(4), 321-331. https://doi.org/10.1016/j.jslw.2012.09.007

Yu, R. (2008). Interaction in EFL classes. Asian Social Science, 4(4), 48-50.

Yuan, F., \& Ellis, R. (2003). The effects of pre-task planning and on-line planning on fluency, accuracy, and complexity in L2 oral production. Applied Linguistics, 24(1), 1-27. https://doi.org/10.1093/applin/24.1.1

Zalbidea, J. (2017). 'One task fits all'? The roles of task complexity, modality, and working memory capacity in L2 performance. The Modern Language Journal, 101(2), 335-352. https://doi.org/10.1111/modl.12389 


\section{Appendix}
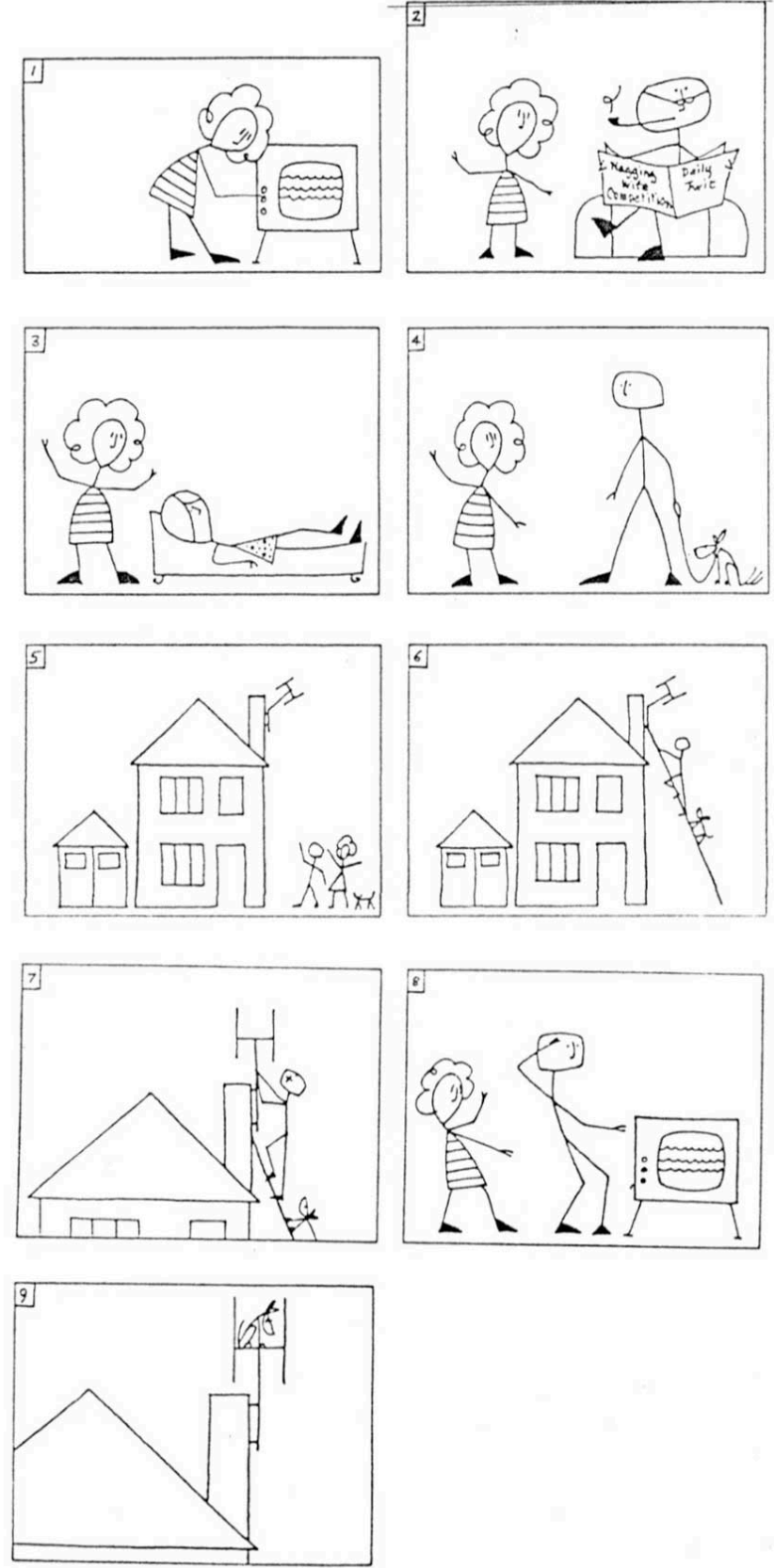


\title{
Address for correspondence
}

\author{
Majid Asgari \\ Department of English Teaching \\ Islamic Azad University \\ Hidaj Branch \\ Hidaj \\ Iran \\ asgarimaj@gmail.com
}

\section{Co-author information}

Sakineh Jafari

Department of English Teaching, Zanjan Branch

Islamic Azad University

sjafari591@yahoo.com

\section{Publication history}

Date received: 13 November 2017

Date accepted: 21 December 2018

Published online: 13 August 2019 